ILIJA MIKIĆ

Institute of Archaeology,

Belgrade, Serbia

email:mikicilija@gmail.com

RICARDO ORTEGA-RUIZ

Instituto de Formación

Profesional en Ciencias Forenses,

London, Great Britain
902.2:572.71"652"(497.11)

904:726.8"652"(497.11)

COBISS.SR-ID 228053260

Original research article

Received: June $7^{\text {th }} 2016$

Accepted: June $20^{\text {th }} 2016$

\title{
BIOMECHANICAL CHANGES IN THE NECK JOINTS IN INDIVIDUALS WITH ARTIFICIALLY DEFORMED SKULLS FROM MEDIANA
}

\begin{abstract}
During archaeological excavations in 2000, two artificially deformed skulls were found in Mediana, at the site west to the palace. These anthropological materials belong to the Great Migration period and it has been previously published. However, the positioning of the head and the changes that have occurred on the first cervical vertebra has not been the subject of any study so far. The first cervical vertebra has been preserved so well that the analysis could be conducted from the perspective of functional static and functional dynamics of the human body. On the other hand, specific morphological changes in the vertebrae possibly caused by artificial deformation have been created.
\end{abstract}

KEYWORDS: SKULL ARTIFICIAL DEFORMATION, NECK JOINT MECHANICAL ALTERATION, PONTICULUS POSTICUS, FORAMEN ARCUALE.

\section{INTRODUCTION ${ }^{1}$}

Research on artificially deformed skulls is usually reduced to attempts to explain the phenomenon, as well as its propagation zone. It occurs in a variety of geographical and chronological zones with different modalities of treatment (Mikić 1994). J. Nemeskéri (1976) made a division that includes the Balkan Peninsula and the so called central Danube European group. Two skulls with artificial deformation which are numbered as 34 and 35 come from Mediana and they are the subject of this paper. As already mentioned, research on artificially deformed skulls had its focus on

1 The article results from the project: Viminacium, Roman city and military camp - research of the material and non material culture of inhabitants by using the modern technologies of remote detection, geophysics, GIS, digitalization and $3 D$ visualization (no 47018), funded by The Ministry of Education, Science and Technological Development of the Republic of Serbia. explaining the technique that has been practiced in the distortion. This particular research aims to try to answer the question about the biomechanical changes that might be occured during the deformation process of the skull and to explain the changes that have occurred on the first cervical vertebrae, which in turn affected the positioning of the head.

\section{ARCHAEOLOGICAL CONTEXT}

During the archaeological excavations of Mediana in 2000, the graves 34 and 35 were discovered (Vasić 2004). According to archaeological finds from the grave 34 (bone double row comb, crescent shape bronze pendant beads of glass paste), this grave can be dated to the end of the $4^{\text {th }}$ or beginning of the $5^{\text {th }}$ century. 
Grave no. 35, that is carved into a powerful stone column and which belongs to the oldest building phase, is considered to be from the same period. Its orientation differs in comparison to all the others from the same period which have been taken into account. In the tomb were found the following archaeological goods: a bronze coin in the right hand, iron buckle and iron knife.

The orientation and skeletal positioning of graves no. 34 and 35 is the following: extended position, arms stretched out next to the body pointing to the east-west and heads on the west side.

\section{METHODS}

Regarding the methodology followed in order to understand the biomechanical changes that the individual suffered possibly as a consequence of the deformed skull in the neck joint, the research has been focused in the macroscopic observation of skeletal shape changes.
The shape and distribution of the occipital surfaces that surround the foramen magnum and the atlas and axis have been evaluated, as well the abrasion of the articular surfaces between all these joints.

On the other hand, this research has also been focused in the physical appearance and biomechanical studies. To proceed with this comparison, the skulls of two individuals with deformed skulls (the individual number 34 and the individual 35) have also been taken into account, as well as another individual with a perfectly functional neck joint: the individual 216 from the necropolis of Pirivoj.

As a result, the main aim is to understand how each and every one of these joints have worked, if they've worked perfectly or to see if there is any biomechanical problem or any variation that may help us comprehend the results of the skull deformation in the neck joint.

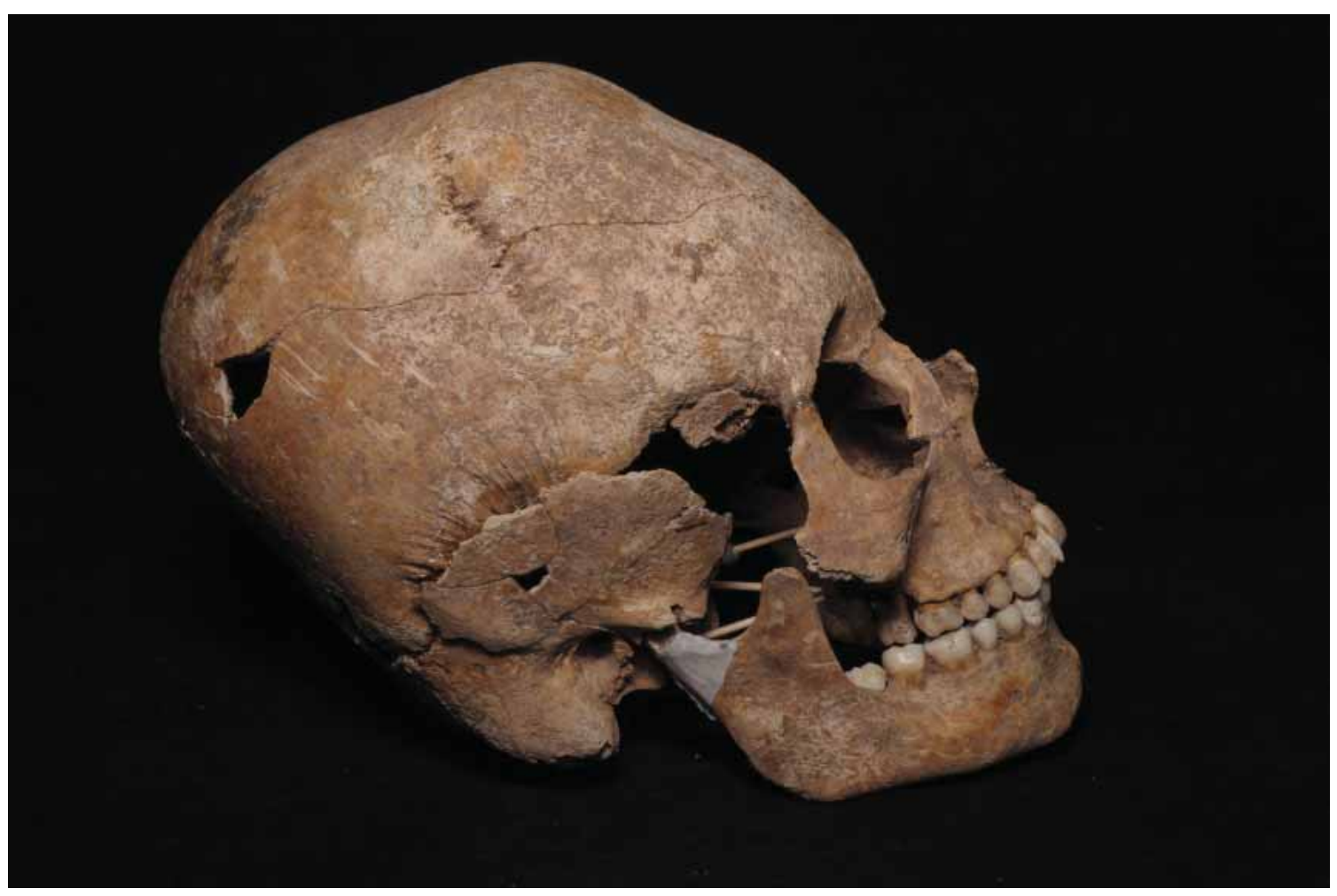

Fig. 1 Skull no.34-Male around 20 years old 


\section{RESULTS}

Given that the previous research has already stated the biological age and sex of the individuals, we will again engage in this issue taking over the existing data. Thus, for determining the sex the recommended criteria given by the group of European anthropologists (Ferembach, Schwidetzky and Stloukal 1979) has been used, as well as Buikstra and Ubelaker (Buikstra and Ubelaker 1994). It must be noted that for the determination of these parameters the postcranial skeleton was not available, so they have been determined only according the basis of the skull. To this end, the taken criteria have been provided by Vallois (Vallois 1937), which refers to the obliteration of cranial sutures, and the degree of coronal obliteration in upper surface of molars, which was formulated Lovejoy (Lovejoy 1985).

According to the criteria stated above, skull no. 34 (fig. 1), despite its gracefulness belonged to a man who was about 20 years old, while skull number 35 (fig. 2) belonged to a robust man who was, at the time of death, about 40 years of age.
The second point to be evaluated in this paper is the analysis of the way in which the deformation in both skulls has affected to the neck joint in both individuals, based on the analysis and evaluation of the shape and abrasion of the joint between occipital bone and the vertebras atlas and axis.

Regarding the individual 34, the first point taken into account was the shape of the occipital bone, in the articular surface with the atlas bone and the disposition of the rest of the bone that connects with the sphenoid bone.

As it can be seen in fig. 3, the shape, instead of being flat, is going upwards and the abrasion, which does not affect the inner part of the articular surface, is incomplete in the nearest part to the foramen magnum. On the other hand, in the atlas vertebra shown in fig. 4 it can be seen that the articular surface and the occipital bone present a complete abrasion with a small quantity of porosities.

The axis vertebra shows also an abnormal shape regarding both articular surfaces of the atlas bone. On one hand, in the superior articular facet of this bone it should be noted that the ventral

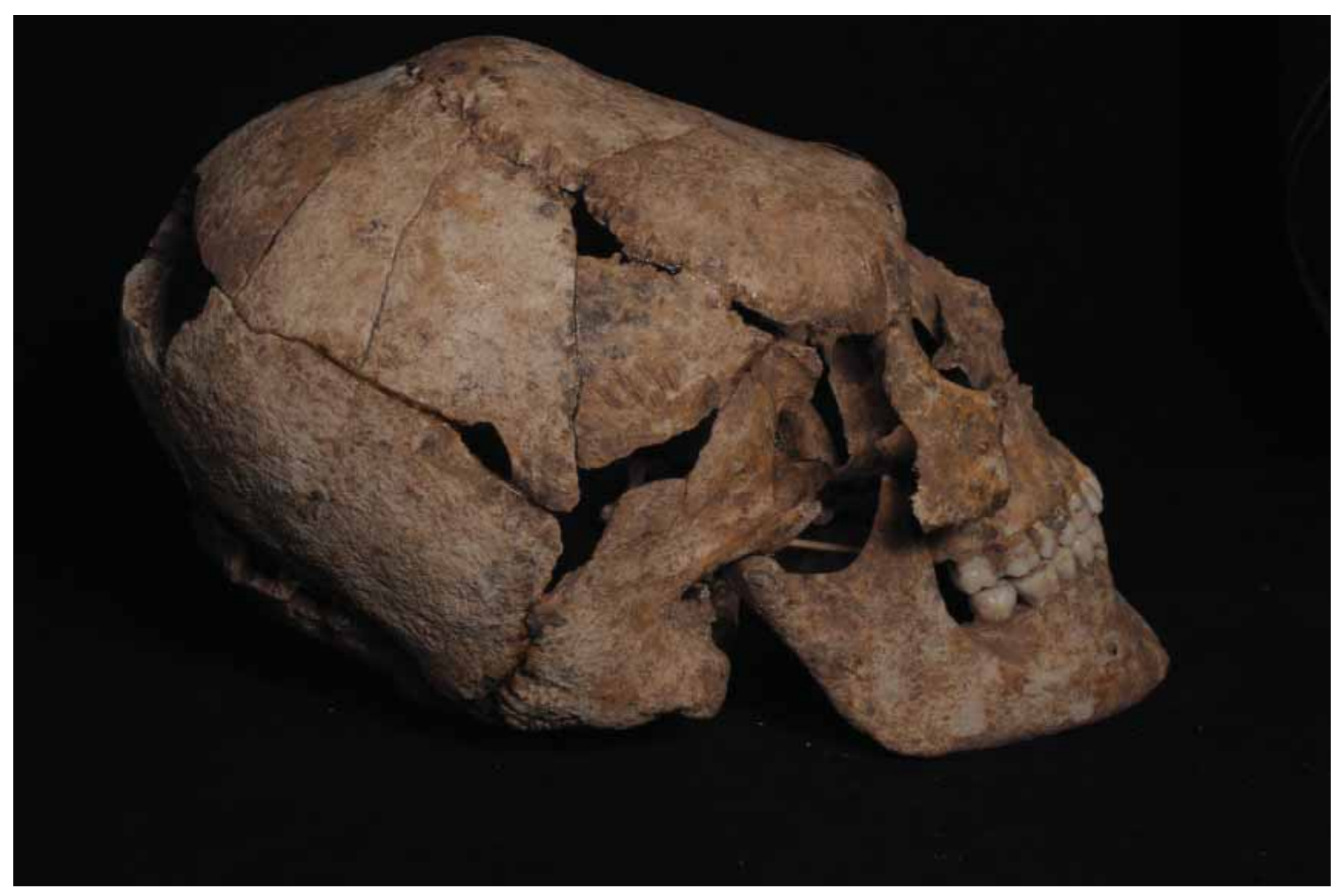

Fig. 2 Skull no.35-Robust male around 40 years old 
zone's articular surface is incomplete.

In fig. 5 we can see a comparison between two axis vertebrae that belong to individuals with the same age at death. The one in the left side of the image belongs to individual 34, which has a deformed skull and the one in the right to individual 216 (necropolis Pirivoj-Viminacium), with no alteration in the skull's shape. The articular surface of the individual 34 is barely altered in comparison to the second one, which can mean that the individual 216 had more movement in this particular joint.

If we focus in the shape and abrasion of the joint between the atlas and axis vertebrae placed in the odontoid process, the articular facet for the anterior arch of atlas, we can see more changes. In fig. 6 we can see that the articular surface only takes half of the odontoid process and barely leaves any space at both sides to provide room for the rotation movement.

In fig. 7 it is shown the complete joint between the skull and the atlas and axis vertebrae of individual 34, where we can see that the joint between the axis and atlas vertebrae does not affect to the whole odontoid process and that the joint located in the articular surfaces between both bones does not fit correctly.

In fig. 8 the comparison between both neck joints (Individual 34 and 35 respectively) is shown. There are pronounced differences between projections of the articular surfaces of the occipital bone. In individual 34 it is visible that it goes upwards, meanwhile the surface of the same bone on the individual 35 is flatter. Also, in the same image it is visible that the articular joint between the atlas and axis vertebrae is more regular in individual 35 what can be caused by aging.

The articular surface between the occipital bone and the atlas vertebra of the individual 35 also displays a regular abrasion but the main change is found in the presence of ossified bilateral foramen in the ventral part of the vertebra, which it is shown in figs. 9 and 10 .

On the other hand, the articular surface placed in the odontoid process (fig. 11) takes the whole process and also has surfaced in both sides to provide the rotation movement for the head. Another

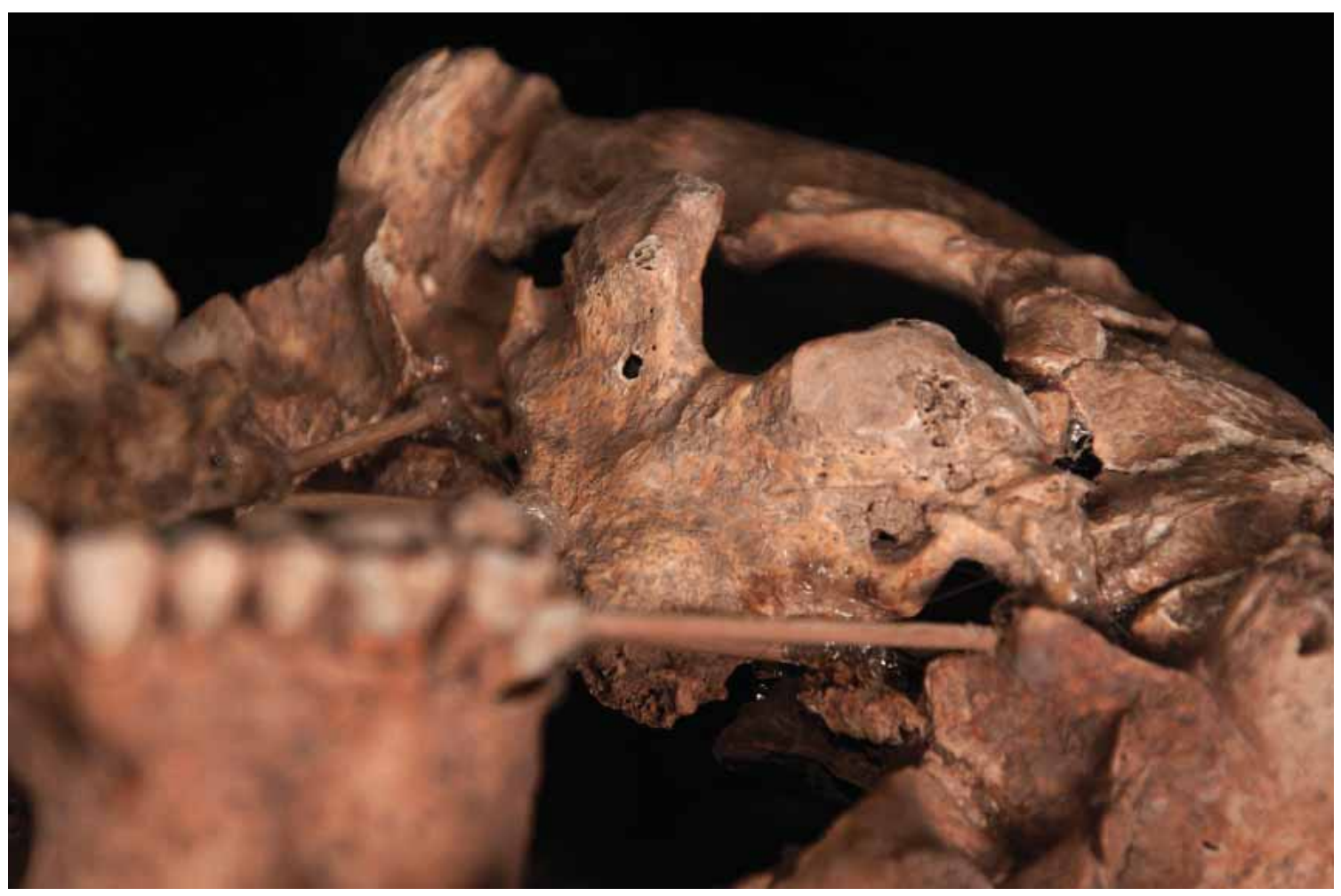

Fig. 3 Skull no. 34-Shape of vertebra and missing part of auricular surface 
important change that can be found in fig. 12 is that the articular surfaces between atlas and axis vertebra do not fit because the atlas bone is narrower.

\section{DISCUSSION}

The foramina that the individual 35 shows in the atlas vertebra are called ponticulus posticus, foramen arcuale or "Kimmerle's anomaly". It is an ossified structure forming a complete or incomplete bridge between the posterior margin of the superior articular facet and the superior margin of the posterior tubercle of the atlas, through which the vertebral artery and the first cervical nerve pass.

The existence of this bridge can cause a higher external pressure over the vertebral artery because it passes through the foramen transversarium from the foramen magnum of the occipital bone. This additional compression could compromise the blood flow resulting in vertebro-basilar insufficiency (Rekha and Rajeshwari 2013).

Historically, the clinical significance of the ponticulus posticus was relevant solely in its association with pathologies as migraine, vertigoes, diplopia, shoulder pain and neck pain, termed as a result as "ponticulus posticus syndrome" (DaGeng et al. 2015). Also, according with the studies of Cakmac (2005) this additional pressure can cause dizziness and headaches.

The causes of this particular ossification has been largely discussed and no conclusion has been reached yet. According with Lamberty B.H.G. and Živanovic S. (1973), this growth seems to be the consequence of the complete or incomplete ossification of the posterior atlantooccipital membrane over the vertebral artery groove.

Among several theories which have been proposed, one of the more related to our particular case is the one formulated by Rekha (2013), which states: "The bony roof of the posterolateral tunnel probably allows greater attachment of posterior atlanto-occipital membrane in quadrupeds where load of the head is supported by extensor muscles of neck, ligaments and posterior atlanto-occipital membrane, but in man weight of the head is borne

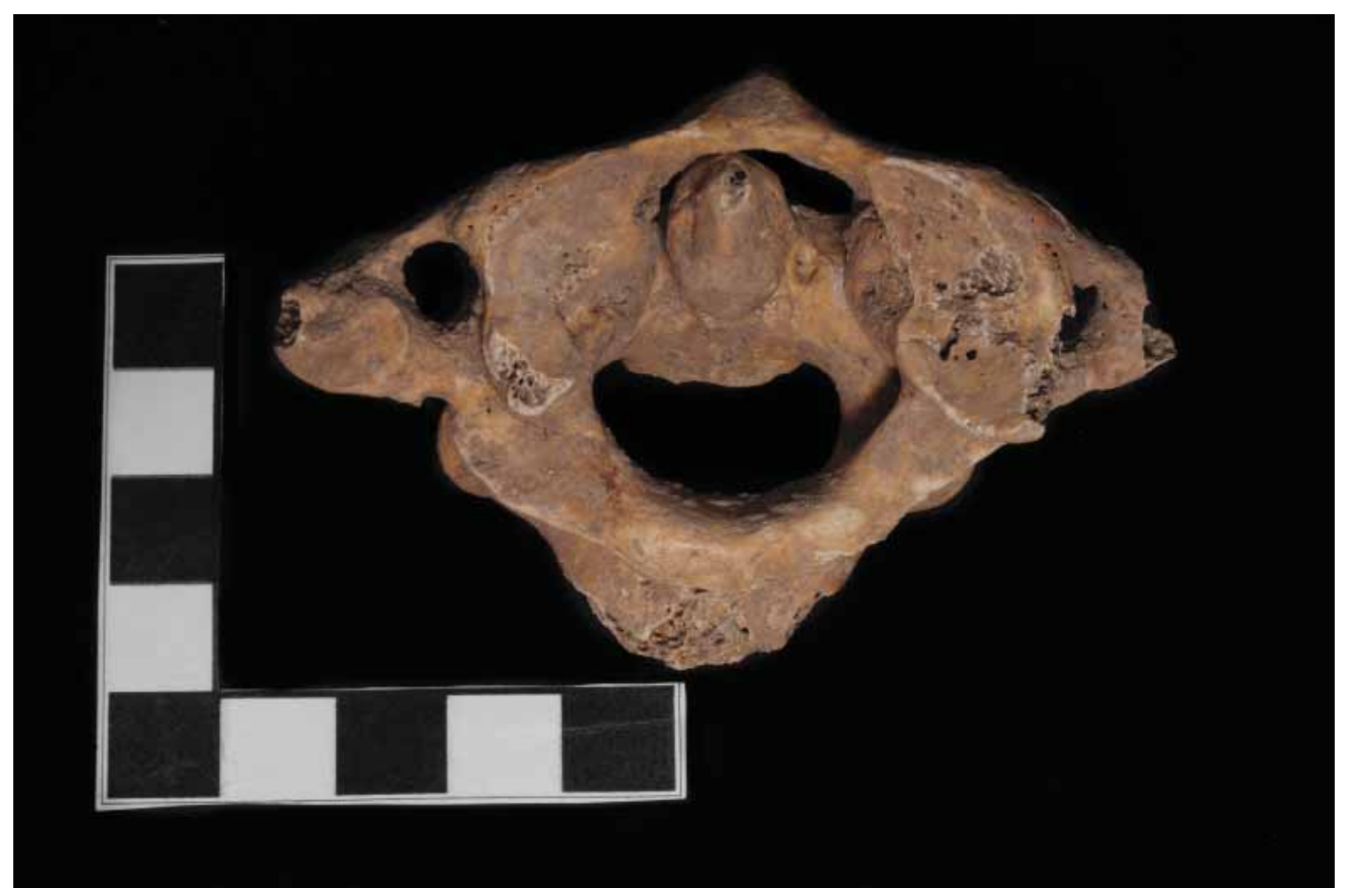

Fig. 4 skull no.34-Presence of abrasion on the Atlas vertebra 


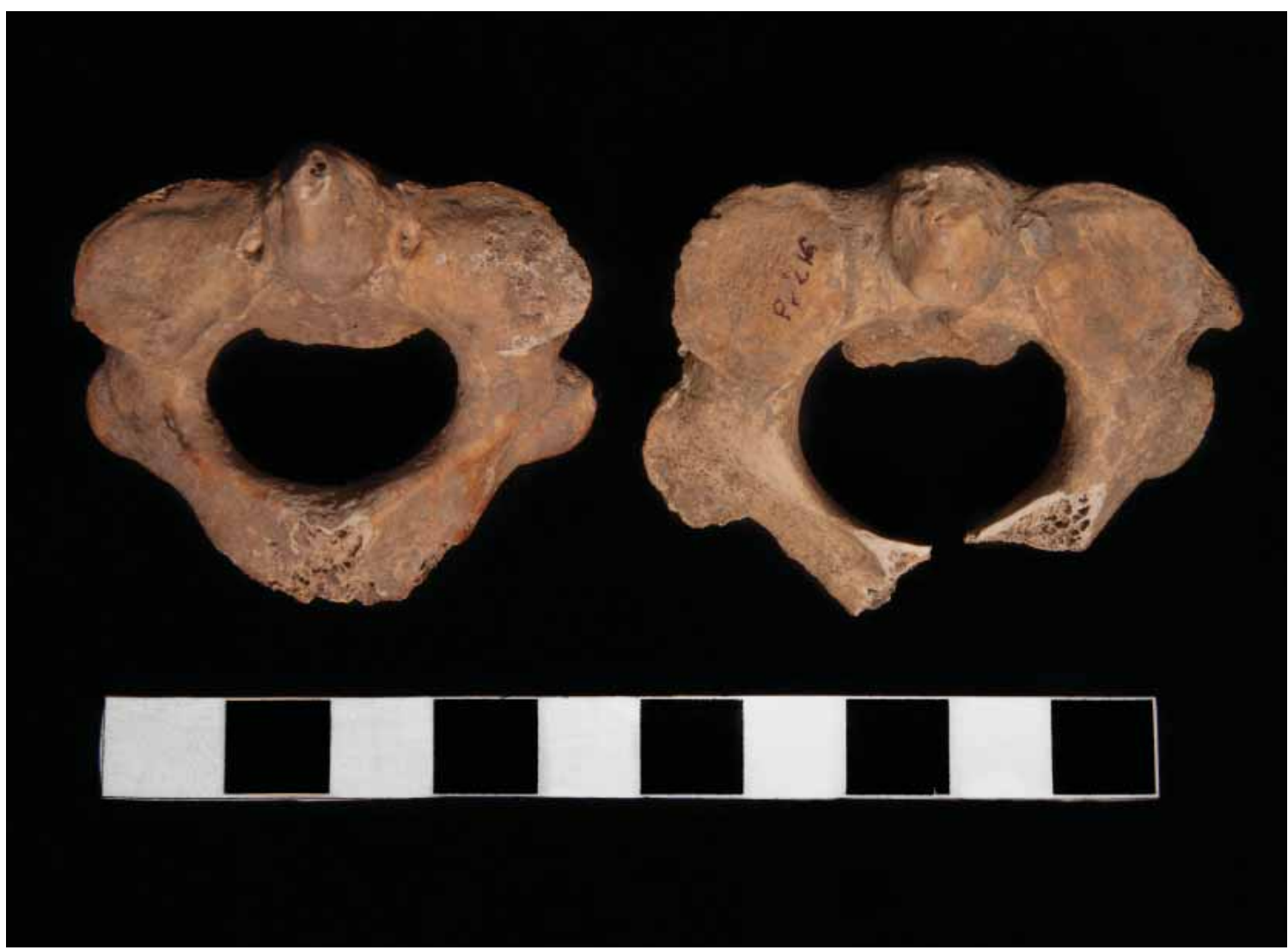

Fig. 5 Comparison between two Axis vertebra which belongs to two individuals at same age of death

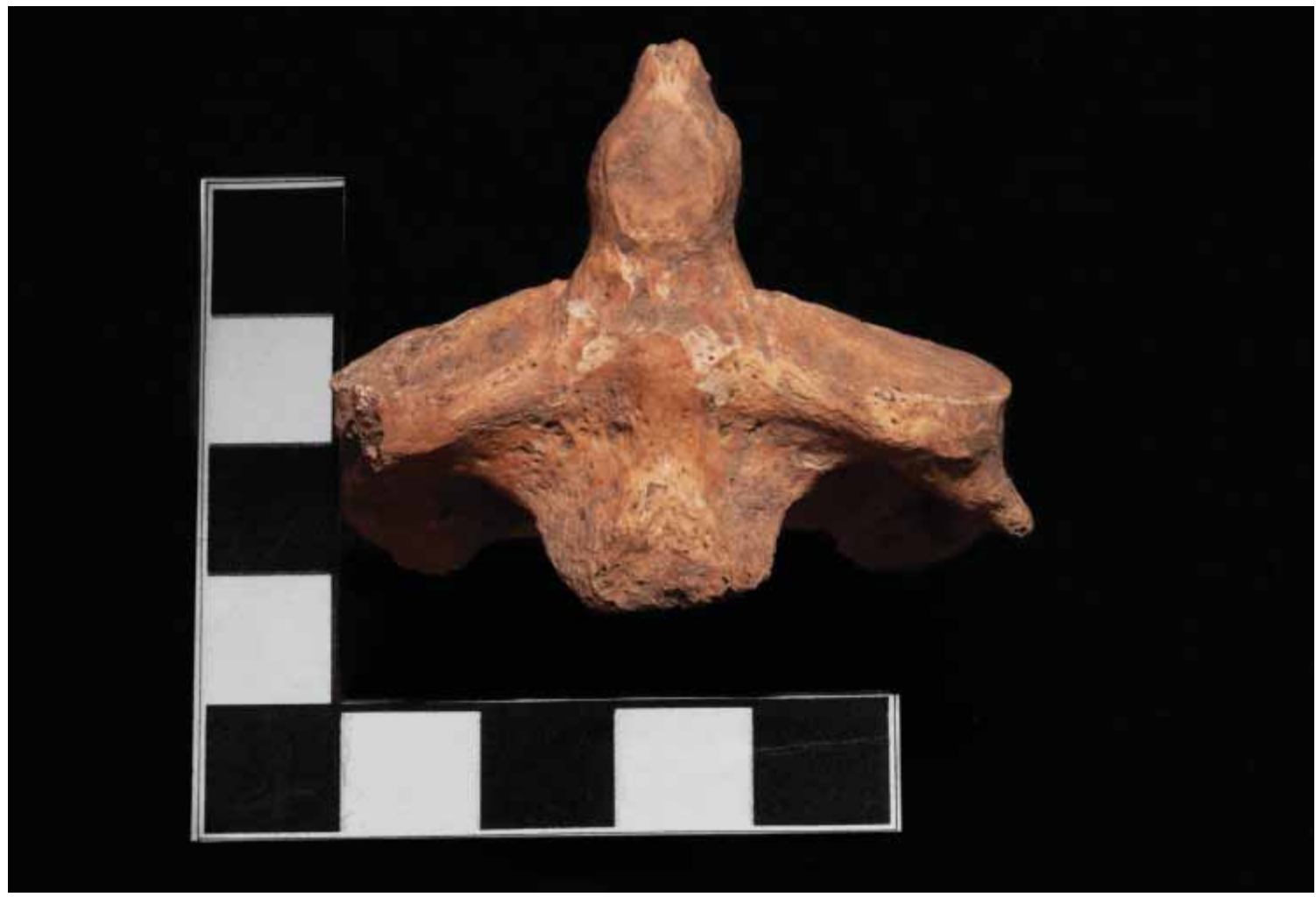

Fig. 6 Individual 34-Odontoid process and auricular surface on vertebra 


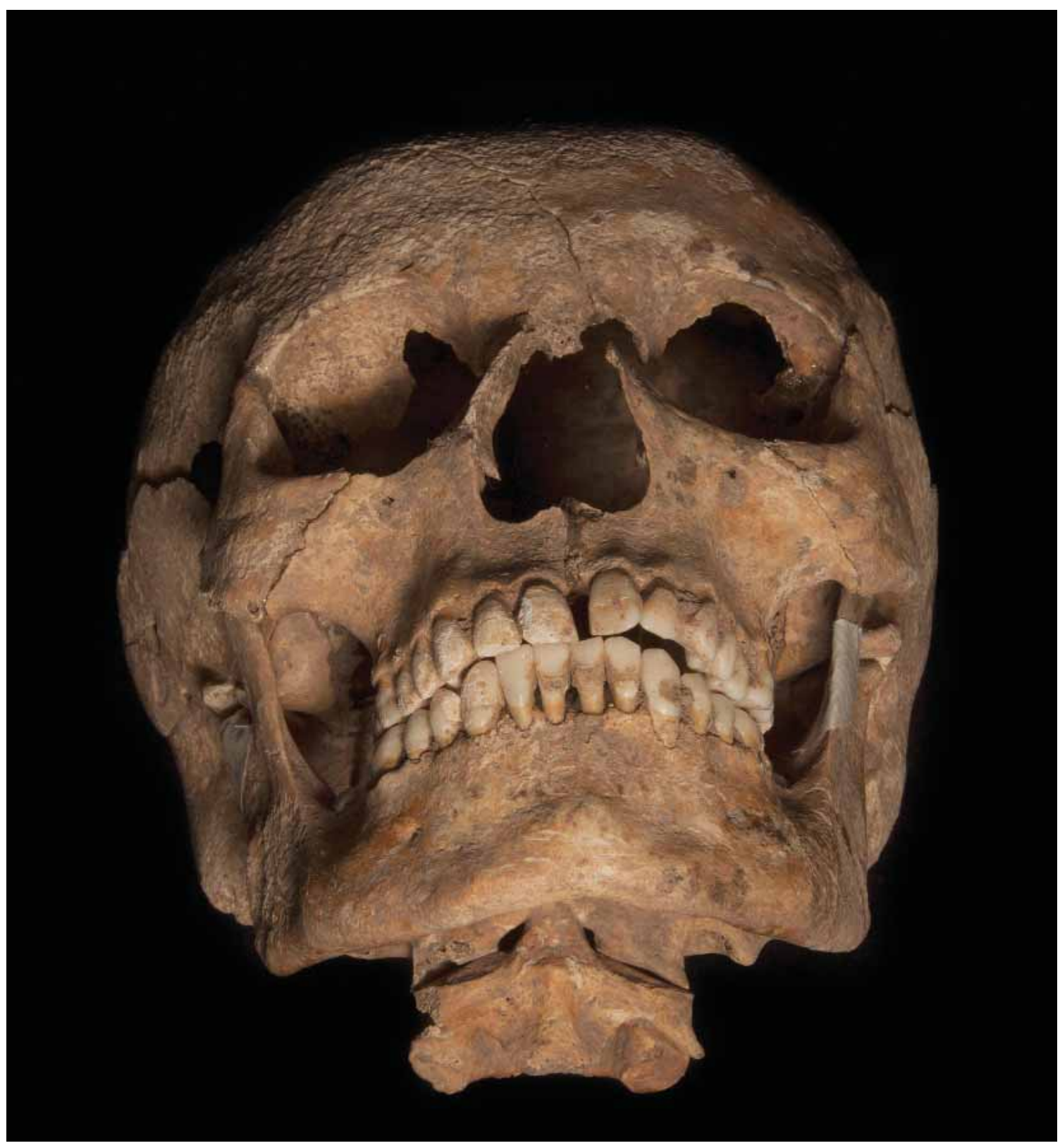

Fig. 7 Reconstruction of the skull position of the individual no. 34

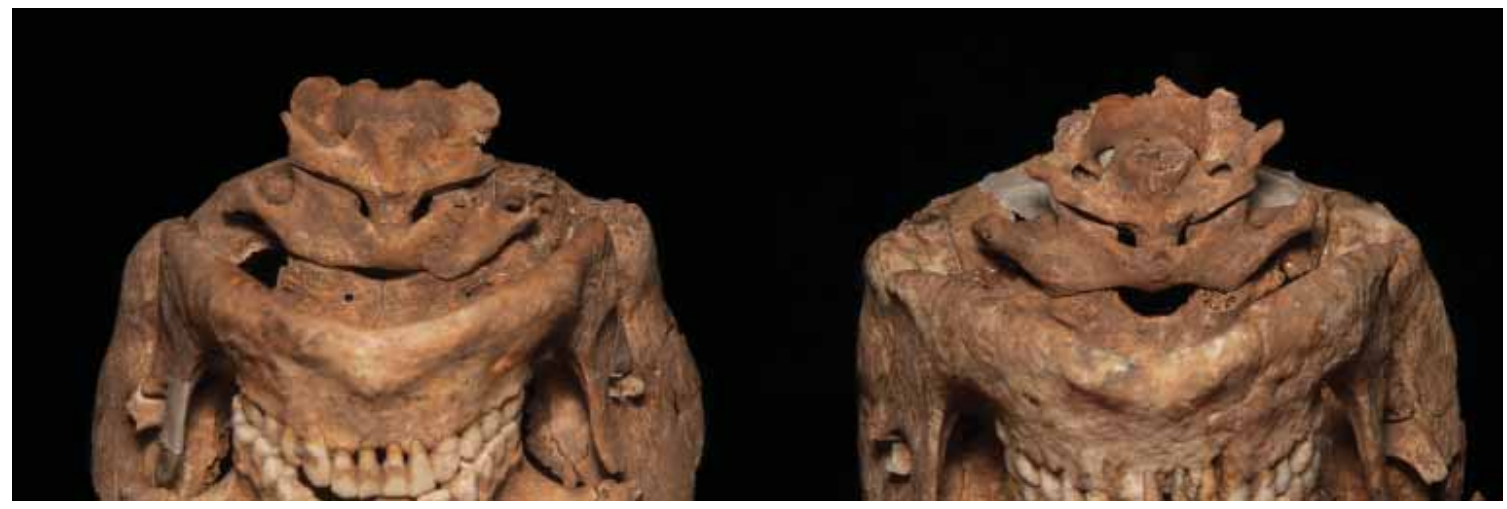

Fig. 8 Comparison between both neck joints (individuals 34 and 35) 


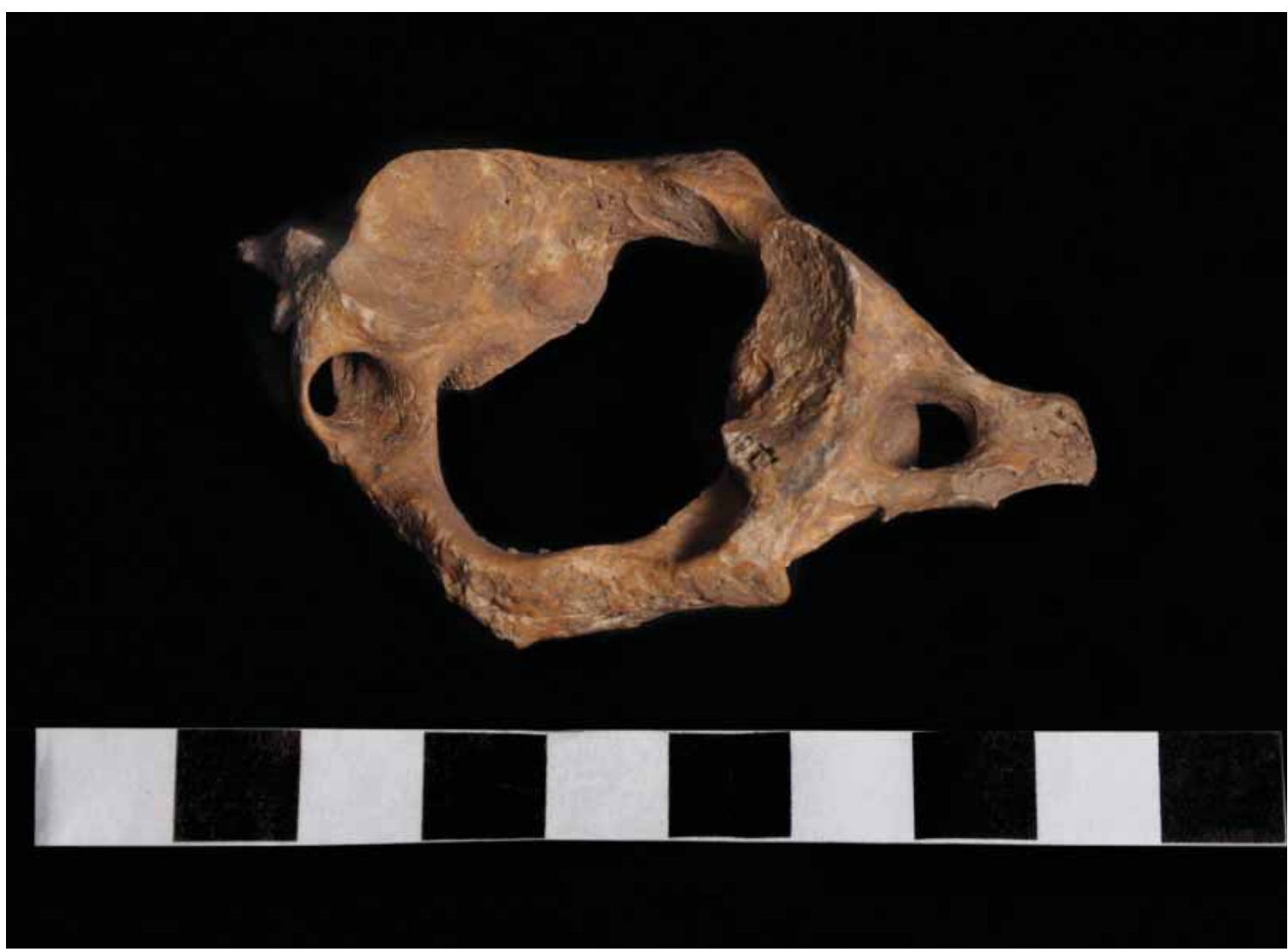

Fig. 9 Presence of the posticilus posticus of the individual no. 34.

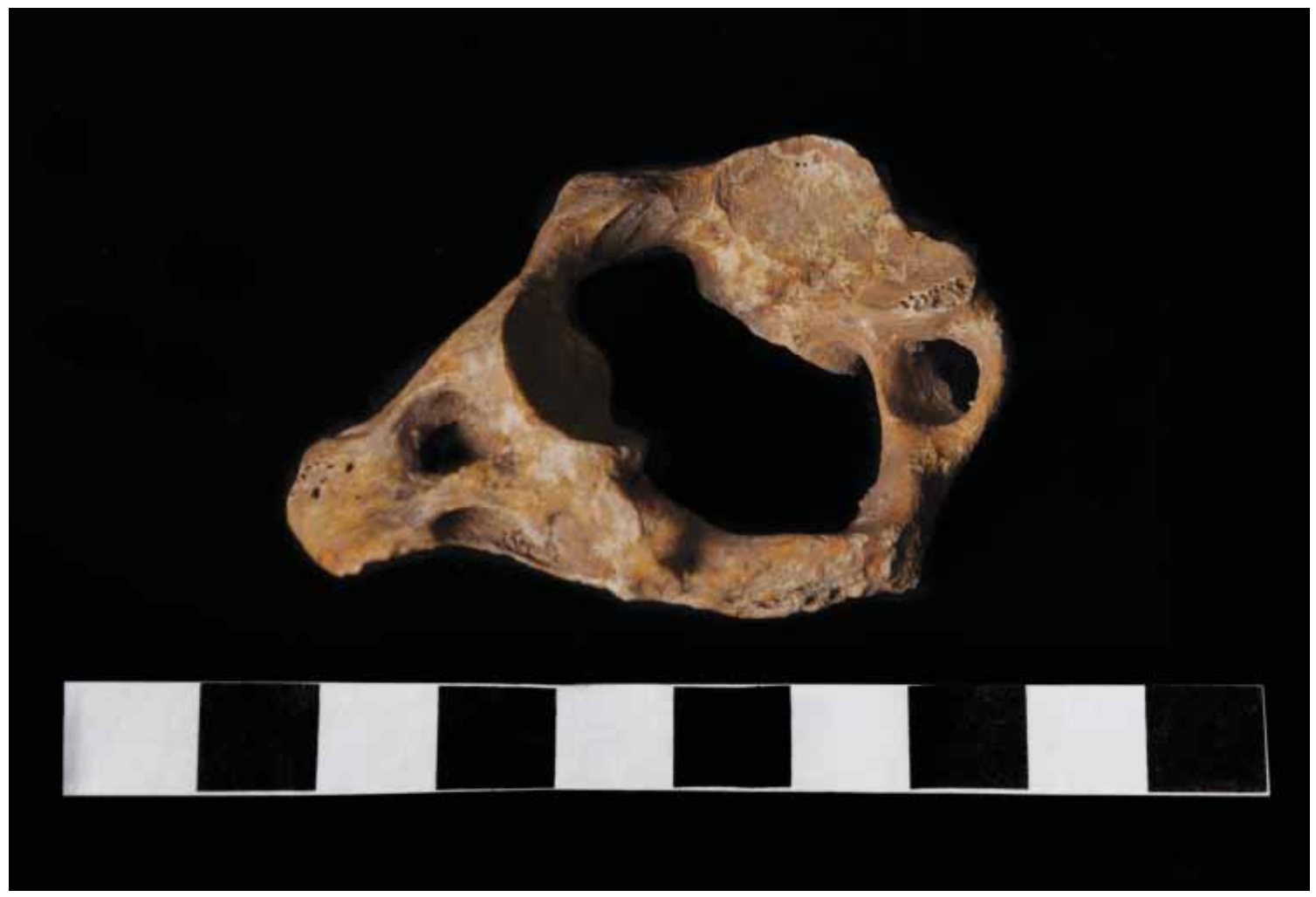

Fig. 10 Posticulus posticus-individual no.34 


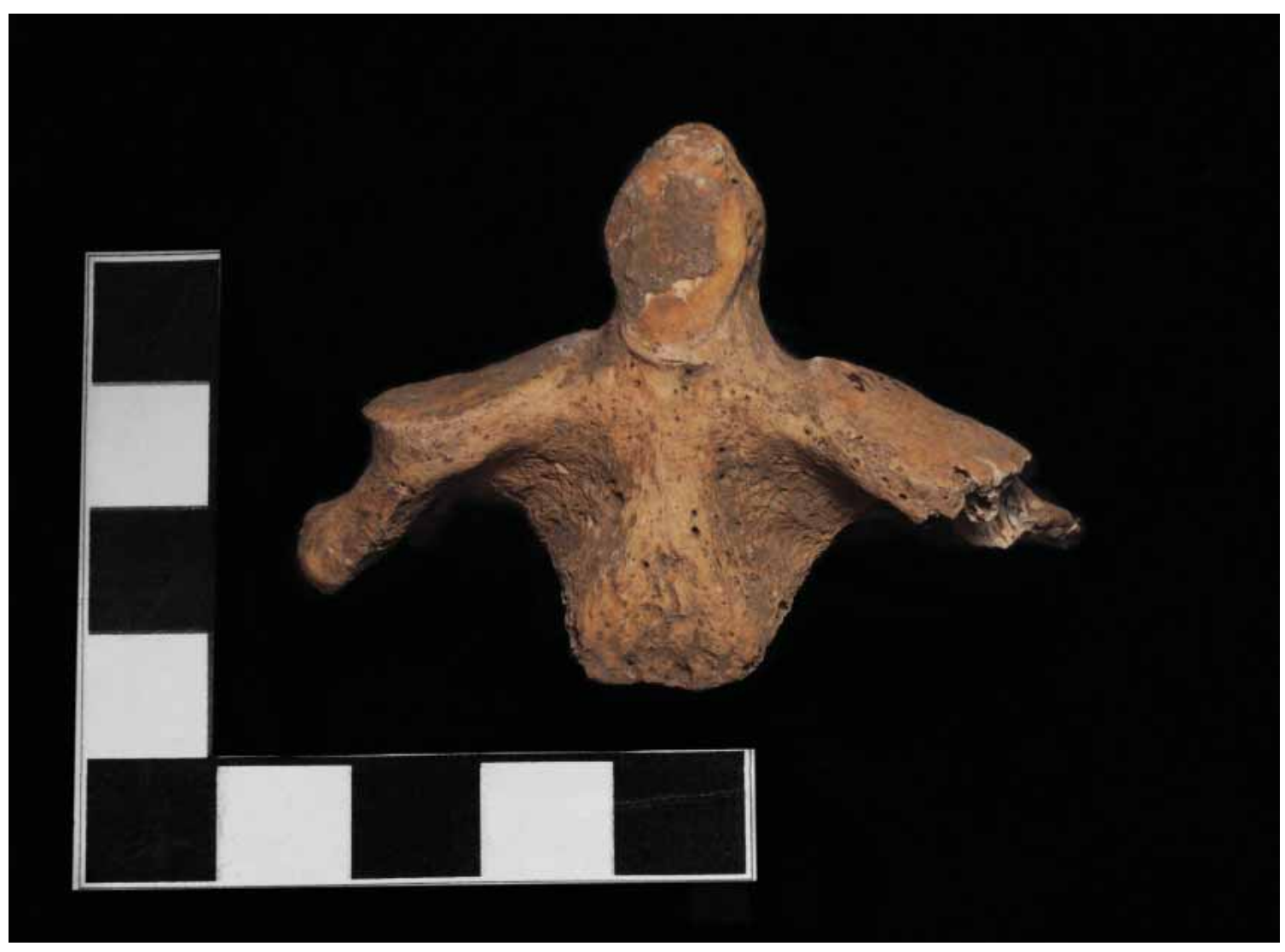

Fig. 11 Individual no.35-Auricular process on the odontoid process

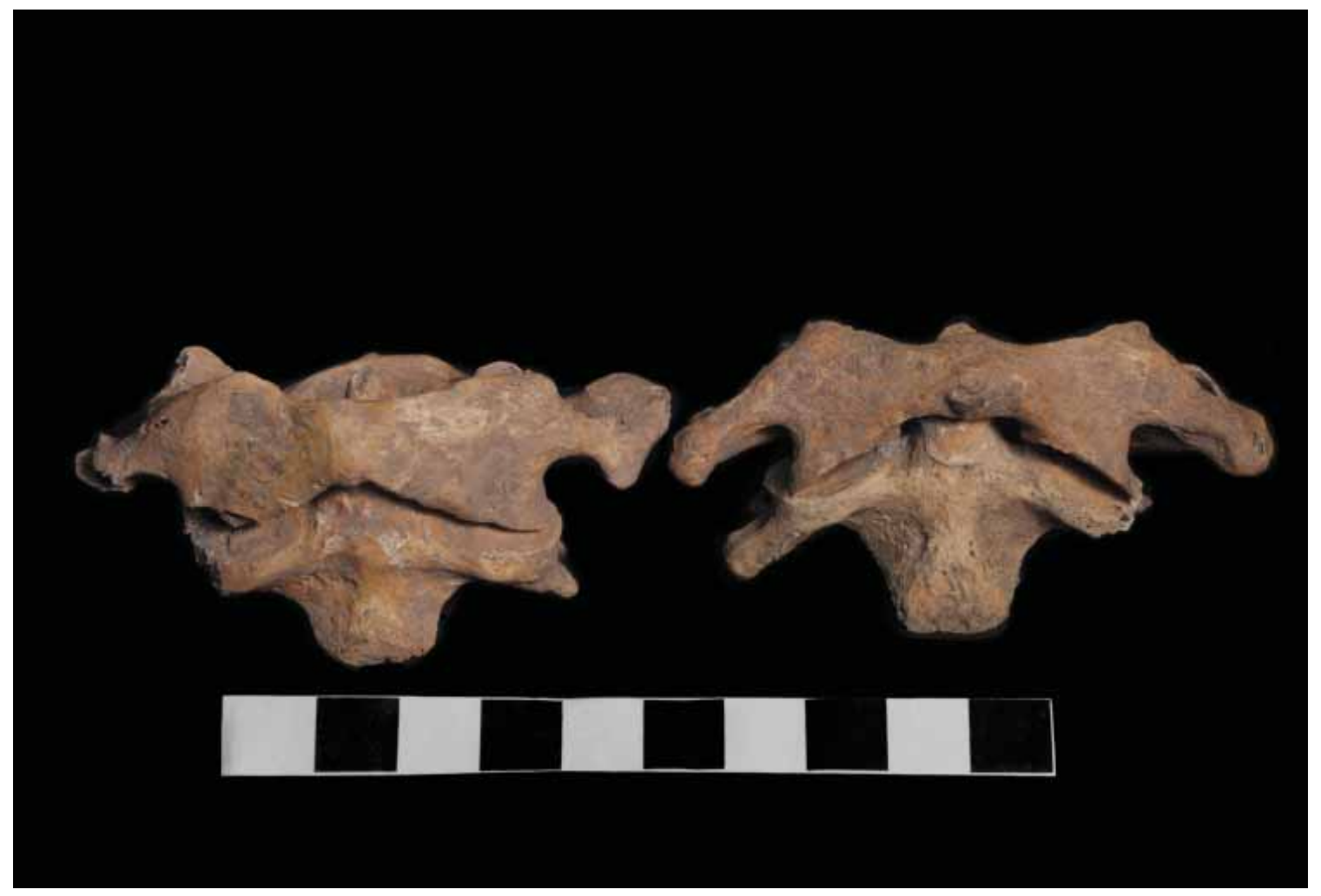

Fig. 12 Changes on the auricular surfaces between atlas and axis. 
by vertical loading of the superior articular facet of atlas the roof of the tunnel has disappeared."

This theory is supported by Schilling et al. (2010) based in the fact that the creation of the bridges does not seem to be affected by aging because they appear also in juvenile population. These results mean that it cannot be considered as an ossification or calcification because it takes time, but rather an ossification with functional significance to protect the passage of the vertebral artery from any damage or compression as a result of craniocervical dynamics.

According to the studies conducted by Dhall et al. (1993) and Pande and Singh (1971), the shape and size of the bridges and the superior articular facet of the atlas vertebra can give us information about the more common head postures and the lateralization of the more dominant muscles of the body. The bigger the bridge and articular facet, the more repetitive use they have suffered. In the particular case of individual 35 we can check that the right facet is more eroded and the bridge is bigger.

\section{CONCLUSIONS}

Regarding the biomechanical changes visible in the neck joint as a possible result of the skull deformation, both individuals have a different response.

The individual 34 presents an evident immobilization of the neck joint. The articular facet placed in the odontoid process is incomplete and barely eroded, which means that the movement visible as a result of the friction between atlas and axis vertebrae was minimal and that the rotation movement was severely decreased.

Likewise, the anterior part of the foramen magnum of the occipital bone, where the articular facets and the atlas bone are found and articulate, displays an abnormal shape. Instead of having a flat disposition, it has modified to be upwards, which allows reducing the pressure over the vertebral artery in its way over the atlas bone.

In addition, the erosion of every joint is very slight and partial, as in the case of the joint between the superior articular facet of the axis vertebra and the inferior articular facet of the atlas bone.

On the other hand, the individual 35 presents more movement in every joint, as the regular abrasion of every articular surface between occipital bone and atlas and axis vertebrae shows, maybe because this person was younger. Also, the shape of the atlas bone has been changed to be narrower, which has a less natural movement between it and the axis vertebra as a consequence.

The presence of the ponticulus posticus, according with the conclusions of part of the historiography consulted could be the result of the natural response of the body towards the additional pressure over the vertebral artery in order to avoid pathologies. This situation could allow to the individual to have a more natural use of the neck joint.

\section{BIBLIOGRAPHY}

Vallois, H. W. 1937

La Durre de la vie chez l'Homme fossile. L'Anthropologie 47: 499-532.

\section{Lamberty B.H.G. and Živanović S. 1973}

The retro-articular vertebral artery ring of the atlas and its significance. Acta Anat 85: 113-22.

Ferembach, D., Schwidetzky, I. and Stloukal, M. 1980

Recommendation for age and sex diagnoses, Journal of Human Evolution 9, 1980: 517-549.

\section{Lovejoy, C. O. et al. 1985}

Fental Wear in the Libben Population: Its Functional Patterns and Role in the Determination of Adult Skeletal Age of Death, American Journal of Physical Anthropology 68: 47-56.

\section{Mitchell, J. 1998}

The incidence of the lateral bridge of the atlas vertebra, Journal of Anatomy 193: 283-285. 
Da-Geng H., Ding-Jun H., Xiang-Yi F., Xin-Liang Z., Bao-Rong H. and Tuan-Jiang L. 2015 Ponticulus posticus, The Spine Journal, 15: 1719.

\section{Rekha B.S. and Rajeshwari T. 2013}

Study of ponticuli in human atlas vertebrae, Journal of Evolution of Medical and Dental Sciences; Vol. 2, Issue 45, November 11: 8849-8855.

Simsek S., Yigitkanli K., Comert A., Acar H.I., Seckin H., Er U., Belen D., Tekdemir I. and Elhan A. 2008

Journal of Clinical Neuroscience 15: 686-688.

\section{Akhtar J. et al. 2015}

A Morpholical study of ponticuli of the human atlas vertebrae and its clinical significance, International Journal of Anatomy and Research 3(4): 1597-02. ???

Schilling, J.; Schilling, A. and Suazo, G. I. 2010 Ponticulus posticus on the posterior arch of atlas, prevalence analysis in asymptomatic patients. International Journal of Morphology. 28 (1): 317322.

Cakmak O., Gurdal E., Ekinci G., Yildiz E. and Cavdar S., 2005

Arcuate foramen and its clinical significance. Saudi Medicine Journal; 26: 1409-13. ???

Dhall U., Chhabra S. and Dhal J.C. 1993

Bilateral asymmetry in bridges and superior articular facets of atlas vertebra. Journal of Anatomical Society of India 42: 23-27.

\section{Pande B.S. and Singh I. 1971}

One sided dominance in upper limbs of human foetuses as evidenced by asymmetry in muscle and bone weight. Journal of Anatomical Society of India 109: 457-459.

\section{REZIME}

\section{BIOMEHANIČKE PROMENE NA NA VRATNIM PRSLJENOVIMA KOD INDIVIDUA SA VEŠTAČKI DEFORMISANIM LOBANJAMA SA LOKALITETA MEDIANA}

\section{KLJUČNE REČI: VEŠTAČKI DEFORMISANA LOBANJA, PONTICULUS POSTICUS, MEDIANA.}

Dosadašnja istraživanja veštački deformisanih lobanja su se svodila uglavnom na istraživanja tehnika bandažiranja kao i na njihovo geografsko prostiranje. Dve lobanje sa Medijane pod brojevima 34 i 35, a koje su bile predmet ovog rada su pružile jedan novi aspekt istraživanja koji se bavi pozicioniranjem glave i promena koje su nastale na vratnim pršljenovima, a kojima je uzrok mogla biti veštačka deformacija lobanje. Istraživanje je pokazalo da je individua koja potiče iz groba br. 34 imala otežano okretanje vrata. Druga individua koja potiče iz groba br. 35 je imala nešto uži i višlji prvi vratni pršljen. To je moglo uzrokovati otežano kretanje vrata. 